\title{
Financial Literacy and Household Savings in Romania
}

\section{Elisabeth Beckmann}

Oesterreichische Nationalbank, elisa.beckmann@gmail.com

\section{Recommended Citation}

Beckmann, Elisabeth. "Financial Literacy and Household Savings in Romania." Numeracy 6, Iss. 2 (2013): Article 9. DOI: http://dx.doi.org/10.5038/1936-4660.6.2.9 


\title{
Financial Literacy and Household Savings in Romania
}

\begin{abstract}
We present new evidence from the Euro Survey of the Austrian Central Bank on the level of financial literacy in Romania and analyze how financial literacy is related to household savings. Less than $5 \%$ of respondents were able to correctly answer the three "core" financial literacy questions on interest compounding, inflation, and risk diversification, with the risk diversification question posing the greatest difficulties. Twenty percent of respondents are able to answer both the interest compounding and inflation questions correctly. Financial literacy levels differ between regions and across rural and urban areas. Older and less-educated individuals perform worst on the financial literacy questions, but those who remember previous periods of economic turbulence during transition perform better. We find that financial literacy is positively and significantly related to saving and investment.
\end{abstract}

\section{Keywords}

financial literacy, household savings, Romania

Creative Commons License

(c) (i) (8)

This work is licensed under a Creative Commons Attribution-Noncommercial 4.0 License

\section{Cover Page Footnote}

Elisabeth Beckmann is an economist in the Foreign Research Division of the Austrian Central Bank, where she is in charge of the Euro Survey. She completed her MS in International Economics and Finance at the University of Glasgow and is studying for her PhD in Economics at the Vienna University of Economics and Business. 


\section{Introduction}

Households in Romania were among those hit hardest by the global financial crisis. As in other countries that have moved from central planning to market economies, one component that might have aggravated the impact of the crisis on households was the role of finance (EBRD 2011).

Consumers in Romania have only had fairly short experience with the use of financial services. The largest country in Southeastern Europe, Romania did not join the first wave of rapid reformers after the collapse of communism. Instead change was gradual and accompanied by severe economic turbulence and banking crises. In 1992 and 1993 Romania experienced hyperinflation; average inflation between 1995 to 1999 was $67 \%$, and the last year of annual average inflation above 20\% was 2002. ${ }^{1}$ In 1990 Romania suffered from a banking crisis, and in 1996 the country experienced a currency crisis (Laeven and Valencia 2008).

Turning to the current situation and comparing selected financial indicators from the World Bank Global Financial Development Database for Romania with an aggregate of high-income countries shows that, similar to high-income countries, bank deposits dominate other assets in Romania. However, deposits as a percentage of Gross Domestic Product (GDP) are 84\% in high-income countries compared to only $31 \%$ in Romania. ${ }^{2}$ Moreover, while the share of household deposits as a percentage of GDP increased over the last decade, in Romania this share is still among the lowest in Central and Eastern Europe. ${ }^{3}$ In addition aggregate data on the saving rate in Romania indicate that gross savings as a percentage of gross disposable income has been close to zero between 2008 and 2010 . Complementing this picture from aggregate data with evidence from micro data used in this analysis we find that around $50 \%$ of respondents in Romania are "banked," i.e., have a bank account, hold savings (excluding cash), or have a loan. At the same time, $44 \%$ of respondents agree with the statement that for them "it takes quite a long time to reach the nearest bank branch." ${ }^{5}$ These figures, of course,

\footnotetext{
1 Figures are from the database of the Vienna Institute for International Economic Studies (www.wiiw.ac.at) as presented in Beckmann and Scheiber (2012).

2 See http://data.worldbank.org/data-catalog/global-financial-development.

${ }^{3}$ By comparison, deposits as a percentage of GDP is close to $40 \%$ in Serbia and around $60 \%$ in Bulgaria.

${ }^{4}$ Data are based on AMECO, the annual macroeconomic database of the European Commission's Directorate General for Economic and Financial Affairs.

${ }^{5}$ The lowest percentage of respondents who agree with this statement is found in Hungary at $17 \%$; the highest percentage is found in Serbia at $47 \%$.
} 
only reflect respondents' perception and are not intended to distinguish demand from supply factors driving the overall level of financial development.

In fact, the memory of the banking crisis during Romania's transition from a planned to a market economy is one of the factors driving households up until now to save in cash rather than using financial intermediaries: Up to $25 \%$ of households with savings in Romania prefer to hold them as cash rather than in a savings account, even if they have a bank account (Stix 2012). This suggests that despite the availability of financial services, a considerable percentage of Romanian households are reluctant to make use of them-even if not doing so is to their financial disadvantage. Cole et al. (2011) discuss two explanations for the limited demand for financial services in emerging markets: On the one hand, financial services involve fixed costs that are too high for low-income individuals; on the other hand, limited demand may be due to limited financial literacy. They find that financial education increases demand for financial services, but only for those with low educational attainment.

For Romania, however, as for other Central, Eastern, and Southeastern European countries, the rapid increase in household debt before the global financial crisis and the subsequent increase in nonperforming loans during and after the global financial crisis showed that households do utilize financial services but might lack the knowledge and experience to manage their finances responsibly. As Lusardi and Tufano (2009) show, lack of knowledge to adequately judge the extent of indebtedness is common among households even in economies that have a long history of financial services for consumers. Gathergood (2012) highlights that lack of self-control is another important reason for consumer overindebtedness. In Romania, as in other emerging markets, a large share of credit was denominated in foreign currency, thus rendering households who were unhedged particularly vulnerable to the sharp exchange rate depreciations after the crisis.

Against this background, we contribute to the literature that studies financial literacy in countries without a legacy of consumer credit and financial services for households (e.g., Klapper and Panos 2011) and provide new evidence on the extent of financial literacy in Romania using internationally comparable indicators. ${ }^{6}$ Our analysis is based on data from the Euro Survey of the Austrian Central Bank. The survey covers ten countries in Central, Eastern, and Southeastern Europe (Albania, Bosnia and Herzegovina, Bulgaria, Croatia, Czech Republic, FYR Macedonia, ${ }^{7}$ Hungary, Poland, Romania, and Serbia), but the present paper will focus on Romania only. Romania provides a compelling case study for several reasons. As we will show, financial literacy levels in Romania are among the lowest in the ten

\footnotetext{
${ }^{6}$ The World Bank conducted a financial literacy survey in Romania in 2010. To our knowledge there is no paper on Romania that uses the standardized financial literacy questions employed in the Financial Literacy around the World project.

${ }^{7}$ The former Yugoslav Republic of Macedonia.
} 
countries covered by the Euro survey and exceptionally low compared to results from various surveys in other countries.

We then focus on the link between financial literacy and saving behavior of households, in particular with regard to retirement savings. The demographic development in Romania has been characterized by long-term population decline due to outward migration of younger people and lower birth rates. This will ultimately put a strain on public finances. Understanding the link between financial literacy and saving behavior in Romania may therefore provide important insights for policy makers seeking to promote saving through financial literacy education.

The next section describes the Euro Survey data set and provides descriptive evidence on financial literacy using the internationally comparable indicators introduced by Lusardi and Mitchell (2011a) and presents breakdowns by sociodemographic characteristics. We then provide descriptive evidence for disparities in financial literacy levels that are specific to Romania before relating financial literacy to the saving behavior of Romanian households.

\section{Data Overview and Summary Statistics}

\section{Data Description}

The analysis is based on data from the Euro Survey of the Austrian Central Bank. The survey covers the ten above-mentioned Central, Eastern, and Southeastern European countries and has been carried out on a semiannual basis since 2007. The survey is a repeated cross section, not a panel.

The survey was designed to investigate the role of the euro in household finances in these countries. It elicits an extensive range of information on household savings, loans, and economic expectations, and a number of publications have used the data to investigate both the level of euroization as well as the reasons behind euroization in these countries. ${ }^{8}$ For some of the countries in the survey, in particular the Southeastern European countries, the euro is a safe haven currency and substitution of euro cash for local currency cash, as well as substitution of foreign currency saving deposits for local currency saving deposits, is widespread. Using the Euro Survey, Scheiber and Stix (2009) calculate an index of overall euroization based on currency and deposit substitution and show that there is a wide variation in euroization levels among countries, ranging from below $10 \%$ in the Czech Republic to above $80 \%$ in Serbia. Euroization in Romania is around $30 \%$

\footnotetext{
${ }^{8}$ For a comprehensive list of publications using the Euro Survey data as well as some descriptive results from the survey, see http://www.oenb.at/en/geldp_volksw/zentral_osteuropa/central_eastern_and_southeastern_europ e.jsp
} 
with currency substitution at above $20 \%$ and deposit substitution at around $40 \%$. Stix (2011) investigates the reasons behind the high euroization levels and in particular the persistence in euroization even after the successful macroeconomic stabilization following the turbulent transition period. Looking at liability euroization, Fidrmuc et al. (2013) show that lack of trust in the stability of the local currency and domestic financial institutions, as well as expectations of shifting to the euro, drive households to borrow in foreign currency.

To date, only two papers use evidence from the Euro Survey on financial literacy. Stix (2012) shows that financially illiterate respondents are more likely to prefer savings in cash over savings in a bank deposit. Beckmann and Stix (2013) address the question of whether the widespread use of foreign currency loans is due to a lack of financial literacy, in particular regarding exchange rate risk. The financial literacy questions were included in two survey waves conducted in late October to early November in 2011 and 2012 respectively. However, the exact three internationally comparable questions on financial literacy (Lusardi and Mitchell 2011a) were only included in 2011, and we will therefore focus on this wave, using the fall 2012 wave for robustness checks only.

In addition to the detailed information on assets and liabilities, the Euro Survey provides information on respondents' sociodemographic characteristics. This additional information is particularly detailed for Romania, and allows for breakdowns by sociodemographic groups as was done for country studies in the Financial Literacy around the World project.

Each survey wave polls a thousand randomly selected individuals age 14 and older in each country. In Romania, the sample is nationally representative at the individual level and is weighted by age, gender, and region of residence. The interviews are face-to-face paper-and-pencil interviews; the questions from the Euro Survey are included as the second section of an omnibus survey. The topic of the other parts of the omnibus survey can vary and are often not related to economics. The average interview time for the Euro Survey section in Romania is thirty minutes. Respondents do not get incentives to answer. We do not impute missing observations but assume nonresponse is random, which admittedly is a fairly strong assumption. For the income question, to which missing values are particularly high, we include a category for "nonresponse." Altogether, this leaves us with a thousand observations for the present analysis.

\section{Descriptive Evidence on Financial Literacy}

In fall 2011, the survey included the three questions on financial literacy - that have become the standard survey questions used to assess financial literacy-first introduced by Lusardi and Mitchell (2011a) in the 2004 US Health and Retirement Study and subsequently used in several countries. The questions were translated 
into Romanian by a professional translator. In English, the exact wording is as follows (correct answers are indicated with two asterisks):

Interest Rate (Numeracy). Suppose you had 100 lei in a savings account and the interest rate was $2 \%$ per year. Disregarding any bank fees, how much do you think you would have in the account after 5 years if you left the money to grow?

More than 102 lei **

Exactly 102 lei

Less than 102 lei

Do not know

No answer

Inflation. Suppose that the interest rate on your savings account was $4 \%$ per year and inflation was $5 \%$ per year. Again, disregarding any bank fees - after 1 year, would you be able to buy more than, exactly the same, or less than today with the money in this account? More

Exactly the same

Less **

Do not know

No answer

Risk Diversification. Do you think the following statement is true or false? "Buying a single company stock usually provides a safer return than a stock mutual fund.”

True

False **

Do not know

No answer

Summary statistics in Table 1 show responses to the financial literacy questions for the whole sample and for the sample of respondents age 25-65. Panel A shows that $41 \%$ of respondents in the whole sample answered the question about interest rates correctly; the percentage is slightly higher for those age 25-65. This level of interest rate literacy is fairly stable across the two survey waves - in fall 2011 it was 41\% and in fall 2012 it was 46\%. Within the Euro Survey, the level of interest rate literacy is comparable to that found in Poland, where the percentage of respondents answering the question correctly is $46 \%$. Compared to interest rate literacy in countries like the United States (65\%, Lusardi and Mitchell 2011b) or the Netherlands (85\%, Alessie et al. 2011) the percentage of interest rate literate respondents is very low in Romania. Results cannot be directly compared with 
those for Russia, as the Russian question was open-ended, but they seem to indicate that numeracy is slightly higher in Romania.

Table 1

Summary Statistics on Financial Literacy Questions

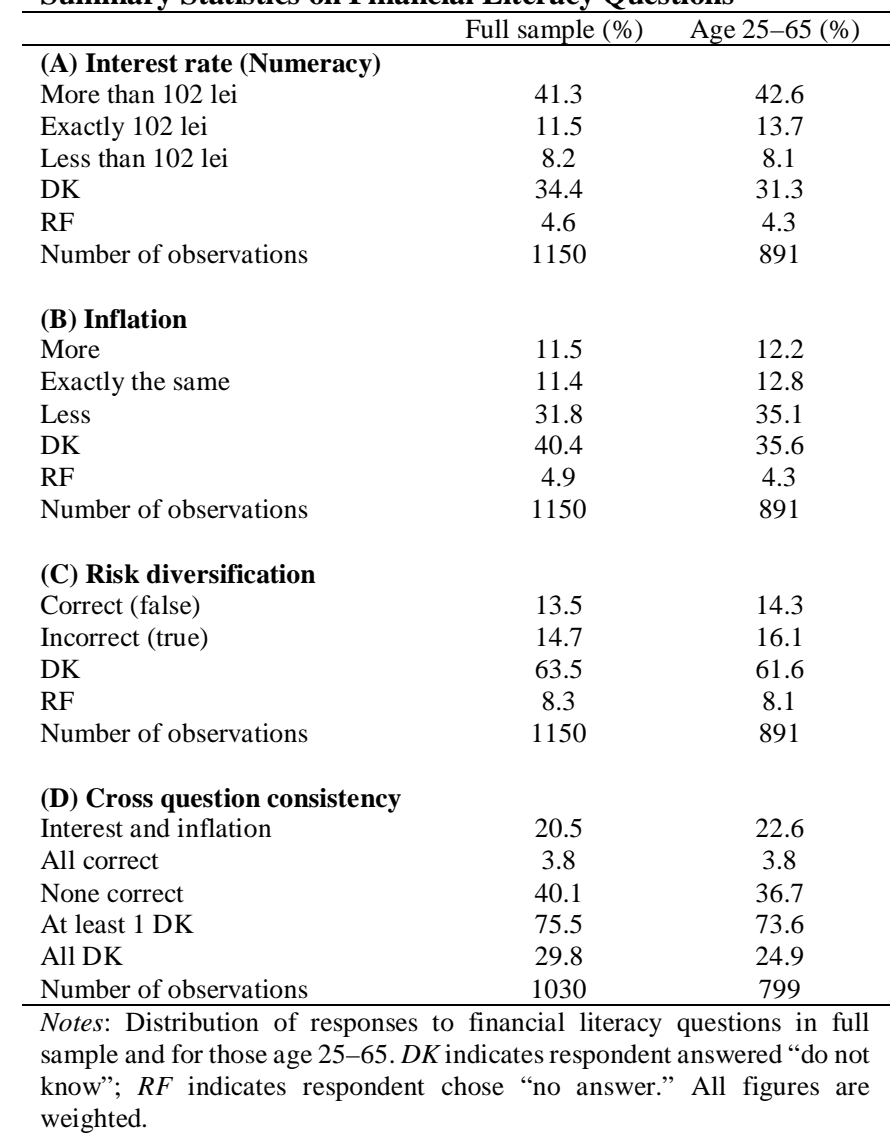

Given that Romania experienced rates of up to $20 \%$ inflation as late as 2002, it is surprising that inflation literacy is even lower, at 32\% for the whole sample and 35\% for those age 25-65 (Panel B). With regard to inflation literacy, Romania is on roughly the same level as Albania (37\%) and Bosnia and Herzegovina (39\%) in the Euro Survey and above Chile (26\%, Behrman et al. 2010). It is notable that the percentage of respondents who answer "do not know" is very high. Perhaps one reason for this is fatigue, as the literacy questions are at the end of the survey; however, the percentage is again fairly stable across survey waves.

Similar to results for industrialized economies, the question on risk diversification posed the greatest difficulty for respondents. Risk diversification 
literacy is as low as $14 \%$. Again, comparing these figures to other results from the Euro Survey, risk diversification literacy in Romania is on a level similar to that of Albania (21\%) and Serbia (24\%). Compared to results from the United States (51\%), these figures are very low indeed. Risk diversification literacy levels in Russia are similar at $13 \%$.

Panel D shows that the percentage of respondents who answered all three questions (that is Interest Rate, Inflation, and Risk Diversification) correctly is very low at $4 \%$. In the ten Euro Survey countries, the only country with a lower percentage of respondents who answer all questions correctly is Albania; in Bulgaria the percentage is also very low, at 7\%. At the same time, close to one-third of respondents indicated they "do not know" the answer to any of the questions-a worrysome result, in particular considering the finding for the United States that "such responses tend to be offered by those who know the least" (Lusardi and Mitchell 2011b).

\section{Who Is Financially Illiterate?}

Previous research has shown that financial literacy differs widely by sociodemographic groups (e.g., Lusardi and Mitchell, 2011c). Table 2 presents the percentage of correct and "do not know" responses to the three financial literacy questions by sociodemographic characteristics.

Table 2

Distribution of Financial Literacy across Demographics

\begin{tabular}{|c|c|c|c|c|c|c|c|c|c|}
\hline & \multirow[b]{2}{*}{$\begin{array}{c}\text { Total } \\
(\%)\end{array}$} & \multicolumn{2}{|c|}{ Interest } & \multicolumn{2}{|c|}{ Inflation } & \multicolumn{2}{|c|}{ Risk } & \multicolumn{2}{|c|}{ Overall } \\
\hline & & $\begin{array}{c}\text { Correct } \\
(\%)\end{array}$ & $\begin{array}{l}\text { DK } \\
(\%)\end{array}$ & $\begin{array}{c}\text { Correct } \\
(\%)\end{array}$ & $\begin{array}{l}\text { DK } \\
(\%)\end{array}$ & $\begin{array}{c}\text { Correct } \\
(\%)\end{array}$ & $\begin{array}{l}\text { DK } \\
(\%)\end{array}$ & $\begin{array}{c}\text { Correct } \\
(\%)\end{array}$ & $\begin{array}{l}\text { DK } \\
(\%)\end{array}$ \\
\hline \multicolumn{10}{|l|}{ Age } \\
\hline Under 35 & 37.9 & 48.8 & 32.7 & 32.7 & 42.6 & 15.2 & 68.0 & 4.5 & 74.4 \\
\hline $36-50$ & 25.1 & 45.0 & 40.1 & 40.1 & 32.1 & 17.6 & 66.1 & 5.3 & 72.4 \\
\hline $51-65$ & 21.1 & 42.9 & 35.8 & 35.8 & 42.3 & 12.6 & 68.7 & 2.2 & 73.8 \\
\hline Older than 65 & 16.0 & 27.8 & 21.0 & 21.0 & 59.6 & 12.1 & 77.7 & 2.2 & 84.8 \\
\hline \multicolumn{10}{|l|}{ Gender } \\
\hline Male & 48.3 & 44.4 & 34.1 & 37.2 & 39.6 & 17.3 & 64.1 & 5.4 & 70.0 \\
\hline Female & 51.7 & 42.2 & 37.8 & 30.0 & 45.1 & 12.4 & 74.0 & 2.4 & 80.6 \\
\hline \multicolumn{10}{|l|}{ Education } \\
\hline $\begin{array}{l}\text { Less than high } \\
\text { school }\end{array}$ & 51.3 & 36.6 & 45.6 & 28.4 & 51.0 & 11.5 & 75.6 & 2.3 & 80.8 \\
\hline High school & 26.3 & 50.7 & 26.9 & 36.6 & 38.6 & 19.1 & 64.6 & 5.6 & 71.8 \\
\hline Some college & 7.7 & 49.3 & 29.3 & 39.1 & 32.0 & 17.9 & 59.1 & 4.5 & 67.7 \\
\hline College graduate & 12.0 & 44.6 & 25.2 & 38.0 & 26.0 & 17.1 & 60.3 & 4.5 & 67.6 \\
\hline Postgraduate & 2.3 & 75.4 & 7.8 & 63.2 & 21.6 & 15.1 & 60.7 & 10.6 & 64.9 \\
\hline \multicolumn{10}{|l|}{ Employment } \\
\hline Self-employed & 2.1 & 58.5 & 13.0 & 49.0 & 16.3 & 21.5 & 46.2 & 7.0 & 52.5 \\
\hline Not working & 32.4 & 44.7 & 37.4 & 30.0 & 49.2 & 10.5 & 73.1 & 3.8 & 79.5 \\
\hline Working & 37.1 & 47.1 & 28.4 & 40.0 & 31.7 & 19.5 & 63.5 & 4.8 & 69.3 \\
\hline Retired & 28.3 & 35.5 & 46.1 & 27.6 & 51.0 & 13.0 & 74.1 & 2.3 & 80.7 \\
\hline
\end{tabular}


The total column describes the composition of the sample. The relatively high proportion of young respondents (37.9\%) is due to the fact that the survey covers respondents age 14 years and older and is in line with results for other countries covered by the Euro Survey. ${ }^{9}$ In the robustness analysis, we excluded respondents who were younger than 18 (thirty-eight respondents).

The statistics about employment require some explanation. Given the low proportion of respondents older than 65 , the percentage of retired respondents may be surprising at first sight. At present, the legal age of retirement in Romania is 65 for men and 60 for women. However, for individuals born before 1950, the legal retirement age is 63 for men and 57 for women. In addition, there are several exemptions; for example, those working in mining and in the military service can retire early. Furthermore, tertiary education counts toward the number of working years required to claim retirement benefits, and if an individual in one year works and is enrolled at the university at the same time, this will count toward his/her pension, i.e., it reduces the pension age by one year. In addition, women who raised three or more children can retire early. ${ }^{10}$ These factors might explain the high proportion of retired respondents in the sample. The proportion of "not working" respondents is also high. The not working respondents include $8 \%$ students, $12 \%$ housewives, $8 \%$ unemployed, and those who refused to answer. Overall, the sociodemographic characteristics of the Romanian sample are in line with those for other countries of the Euro Survey and, more important, have been similar across the eleven survey waves carried out to date. In addition, we compared the results with those of the World Bank's Financial Literacy Survey and found a similar sociodemographic distribution, with $37 \%$ retired respondents and $41 \%$ working respondents.

Regarding the distribution of financial literacy by sociodemographic characteristics, we find financial literacy is lowest among the elderly (under age 65) and highest in the 36-50 age bracket. The hump-shaped pattern of financial literacy is not as pronounced as in industrialized countries, though, and the "hump" occurs at a younger age (36-50 instead of 51-64). ${ }^{11}$ As in Russia (Klapper and Panos 2011), respondents in the youngest age bracket (under age 35) show a relatively high level of financial literacy. In line with results from other studies), we find a significantly lower level of financial literacy among women and a higher propensity of women to answer "do not know" (e.g., Lusardi and Mitchell, 2011c). As expected, financial literacy is positively related to education, with individuals with postgraduate education showing the highest percentage of correct responses

\footnotetext{
${ }^{9}$ Appendix Table A2 provides descriptive statistics for Romania as well as for the remaining nine Euro Survey countries.

${ }^{10}$ I am grateful to Radostina Ilieva for her input on the Romanian pension system.

${ }^{11}$ See the next section for a possible explanation.
} 
and the lowest percentage of “do not know" responses. Surprisingly, however, college graduates have a lower level of financial literacy than high school graduates. While it is difficult to find an explanation for this result, it is found in other countries covered by the Euro Survey. Appendix Table A1 provides the percentage of respondents who correctly answered the interest literacy question for the remaining nine countries of the Euro Survey by education groups. It shows that financial literacy does not consistently increase with education in several other countries and that, similar to Romania, high school graduates in Croatia and the FYR Macedonia are more likely to answer the interest rate literacy question correctly than those who have a college degree.

Financial literacy is also related to labor market status. Financial literacy is highest for self-employed respondents. This has also been found for Italy (Fornero and Monticone 2011), where the difference in literacy between employed and self-employed respondents is, however, not as large as in Romania. Among the retired and those not working, financial literacy is lowest, a pattern also found in other countries, e.g., Germany (Bucher-Koenen and Lusardi 2011).

\section{Disparities in Financial Literacy Levels}

Previous research identified several country-specific factors that are relevant for financial literacy. For example, Alessie et al. (2011) show that financial literacy differs with religious affiliation in the Netherlands; Fornero and Monticone (2011) find large regional differences in financial literacy in Italy; and Klapper and Panos (2011) present evidence of disparities in financial literacy across urban and rural areas in Russia. We find that some of these disparities in financial literacy levels are also present in Romania. First, we confirm regional differences in financial literacy, which are in part correlated with disparities in regional macroeconomic indicators as Fornero and Monticone (2011) found for Italy. Figure 1 shows the percentage of financially literate respondents by region. In Romania, the poorest region is the northeast, followed by the southeast. Interest rate (Figure 1, left panel) and inflation literacy (Figure 1, right panel) are among the lowest in these regions. Comparing the ten Central and Eastern European countries covered by the Euro Survey, regional disparity in financial literacy levels is among the highest in Romania. If we control for sociodemographic characteristics, we still find significant geographical variations in financial literacy. ${ }^{12}$

\footnotetext{
${ }^{12}$ Results available upon request from the author. We estimate linear probability models with dummy variables for answering each of the financial literacy questions correctly as the dependent variables, control for sociodemographic characteristics, and include regional fixed effects. The regional fixed effects are highly significant. It would be interesting to conduct an in-depth investigation of the geographical variations in financial literacy, as Bumcrot et al. (2013) do for the United States. However, this is only possible to a limited extent due to lack of regional data.
} 

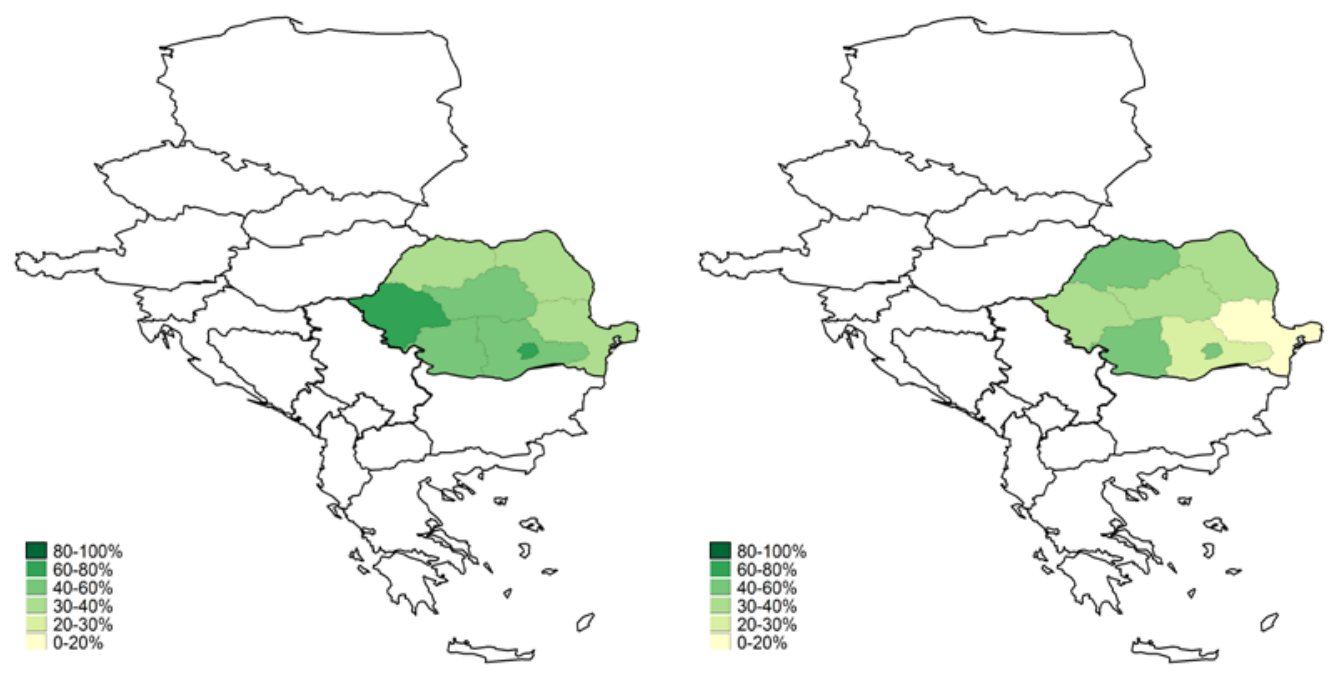

Figure 1. Financial literacy at the regional level. The left panel shows the percentage of respondents in each region who answered the interest question correctly. The right panel shows the percentage of respondents by region who answered the inflation question correctly.

Second, a further disparity in the level of financial literacy is between urban and rural areas (Table 3). Financial literacy in rural areas is consistently lower, and the percentage of respondents indicating they do not know the answer is significantly higher. Again, this is in line with results from previous research; in particular, Klapper and Panos (2011) show that financial literacy is significantly lower in the rural areas of Russia.

Table 3

Financial Literacy: Urban-Rural Differences and Transition Experience

\begin{tabular}{|c|c|c|c|c|c|c|c|c|c|}
\hline & \multirow[b]{2}{*}{$\begin{array}{c}\text { Total } \\
(\%)\end{array}$} & \multicolumn{2}{|c|}{ Interest } & \multicolumn{2}{|c|}{ Inflation } & \multicolumn{2}{|c|}{ Risk } & \multicolumn{2}{|c|}{ Overall } \\
\hline & & $\begin{array}{c}\text { Correct } \\
(\%)\end{array}$ & $\begin{array}{l}\text { DK } \\
(\%)\end{array}$ & $\begin{array}{c}\text { Correct } \\
(\%)\end{array}$ & $\begin{array}{l}\text { DK } \\
(\%)\end{array}$ & $\begin{array}{c}\text { Correct } \\
(\%)\end{array}$ & $\begin{array}{l}\text { DK } \\
(\%)\end{array}$ & $\begin{array}{c}\text { Correct } \\
(\%)\end{array}$ & $\begin{array}{l}\text { DK } \\
(\%)\end{array}$ \\
\hline Size of Town & & & & & & & & & \\
\hline Less than 5,000 & 44 & 39.0 & 44.2 & 29.3 & 51.7 & 10.9 & 74.7 & 2.0 & 80.6 \\
\hline Greater than 500,000 & 32 & 48.7 & 24.9 & 35.6 & 31.7 & 20.1 & 61.8 & 5.8 & 69.4 \\
\hline Transition experience & & & & & & & & & \\
\hline Remembers hyperinflation & 65 & 49.1 & 28.2 & 39.0 & 33.6 & 17.7 & 65.1 & 4.3 & 72.1 \\
\hline $\begin{array}{c}\text { Does not remember } \\
\text { hyperinflation }\end{array}$ & 35 & 43.6 & 27.8 & 31.3 & 35.6 & 18.2 & 60.3 & 3.7 & 66.0 \\
\hline
\end{tabular}

Notes: Distribution of responses to financial literacy by rural / urban areas and by transition experience. The total column describes the composition of the sample. The omitted category for size of town is localities with 5,000 to 500,000 residents and constitutes $24 \%$. For transition experience, respondents answering "do not know" or "no answer" are excluded so figures for total sum up to 100. The remaining figures (correct and DK) show the percentage of correct and DK responses to the financial literacy question within the group of, e.g., respondents living in villages. The percentage of wrong answers is not shown, hence figures do not sum to 100 in the rows. 
Third, we find some indication that differences in financial literacy can also be identified among different ethnic groups. ${ }^{13}$ The sociodemographic information in Romania also includes ethnicity (Romanian, Hungarian, Roma, German, Jewish, other). Less than $1 \%$ of respondents falls within the categories German, Jewish, or other. Around $5 \%$ of respondents state they are Hungarian, and around $2 \%$ state they are Roma. ${ }^{14}$ With the necessary degree of caution, given the low number of observations for these categories, we find that financial literacy levels do not differ significantly between Hungarians and Romanians, but are lower for Roma. ${ }^{15}$ In particular, the percentage of "do not know" answers is very high for respondents who state they are Roma.

Finally, we show that the transition experience and, in particular, memories of economic turbulence play a role in financial literacy (Table 3). This might explain the difference in the hump-shaped pattern in financial literacy with regard to age between Romania and other countries, as discussed in the previous section. It could be argued that the older generations are less financially literate in countries that moved from planned to market economies due to their lack of experience in managing their finances. At the same time, they lived through times of economic turbulence and this could have raised their awareness and understanding of economic concepts such as inflation. To shed some light on this, we utilize two questions from the survey on memories of previous economic turbulence. First, respondents are asked whether they "remember periods of high inflation during which the value of the leu dropped sharply." While these memories are obviously correlated with age, they provide a much more specific measure of personal experience, which could have an effect on financial literacy. The bottom panel in Table 3 divides respondents into those who remember hyperinflation and those who do not: Interest rate and inflation literacy is higher among those who have an active memory of previous economic crises. The results are similar if we divide the sample by responses to the following question: "If you think back in time to periods of economic turbulence that happened prior to 2008, e.g., very high inflation, banking crises, or restricted access to savings deposits, at that time, did you personally incur a financial loss due to such events?” These results provide some indication that the experience of turbulent economic transition affected saving behavior (Stix 2012) but also increased financial literacy. ${ }^{16}$

\footnotetext{
${ }^{13}$ Results not shown in Table 3.

${ }^{14}$ This is in line with results from the World Bank Financial Literacy Survey in Romania, where 3\% are Roma and 7\% are Hungarian.

15 The World Bank survey finds that "financial outsiders tend to be overrepresented about (...) Roma,” p. 17.

${ }^{16}$ Of course, these results are only descriptive, and it could be that memories of turbulent economic transitions are correlated with other factors that in turn drive financial literacy. For example,
} 


\section{Does Financial Literacy Matter? Saving and Financial Literacy}

Previous research has shown that financial literacy is correlated with financial decisions (e.g., Cole et al. 2011). Financially literate households tend to avoid overindebtedness (Lusardi and Tufano 2009) and are less likely to take on foreign currency debt (Beckmann and Stix 2013). Financial literacy is also associated with stock market participation (Van Rooij et al. 2011), risky asset holdings (Cardak and Wilkins 2009), and portfolio choice (Christelis et al. 2010; Abreu and Mendes 2010). Importantly, financially literate individuals are more likely to plan for retirement and accumulate wealth, as the papers that are part of the Financial Literacy around the World project show (Lusardi and Mitchell 2011c). More recently, Jappelli and Padula (2013) present a model of intertemporal consumption smoothing and financial sophistication and empirically show that consumption growth is positively correlated with financial literacy.

Our analysis follows those in the Financial Literacy around the World project. While we do not have direct evidence from the Euro Survey on retirement planning, we have detailed information on the saving behavior of households, which we will utilize to study whether financial literacy is correlated with the saving behavior of Romanian households. Our measure for saving behavior is based on the following question, posed to all respondents:

There are several ways in which you can hold savings. For example, one can hold cash, use bank accounts, have life insurance, hold mutual funds, etc. Please take a look at this card that lists various savings instruments_could you please select the ones you are using and rank them according to the amounts you have saved on the respective instrument. Please refer to savings you hold personally or together with your partner.

Cash

Savings Deposit

Life Insurance

Mutual Funds

Stocks

Pension Funds

education during the socialist regime placed an emphasis on mathematics, and the majority of those who remember previous economic turbulence were educated in this regime. However, while strong mathematics education would help in answering the interest question, correctly answering the inflation and especially the risk diversification question require financial and economic in addition to mathematical knowledge. 
Bonds

Current Account

Other

I have no savings

Do not know

No answer

We define all respondents who state they have savings, including those who name cash and current account, as respondents with savings. Those who say they have no savings are respondents without savings. It is important to note that responses do not contain information on amounts saved. Table 4 shows that interest rate and inflation literacy is higher among respondents with savings. There is no clear difference with regard to risk diversification literacy. In contrast to findings for Russia (Klapper and Panos 2011), the percentage of "do not know” responses is significantly higher for respondents without savings.

Table 4

Financial Literacy for Savers and Nonsavers

\begin{tabular}{lcc}
\hline & $\begin{array}{c}\text { Respondents with } \\
\text { savings (\%) }\end{array}$ & $\begin{array}{c}\text { Respondents with no } \\
\text { savings (\%) }\end{array}$ \\
\hline (A) Interest question & 46.9 & 38.8 \\
More than102 lei & 14.5 & 9.7 \\
Exactly102 lei & 11.3 & 4.8 \\
Less than 102 lei & 24.1 & 41.1 \\
DK & 3.2 & 5.6 \\
RF & & \\
(B) Inflation question & 15.4 & 9.3 \\
More & 17.0 & 7.1 \\
Exactly the same & 34.1 & 30.3 \\
Less & 30.7 & 47.8 \\
DK & 2.9 & 5.6 \\
RF & & \\
(C) Risk diversification question & 17.9 & 13.4 \\
Correct (false) & 17.8 & 10.1 \\
Incorrect (true) & 57.8 & 67.9 \\
DK & 6.6 & 8.6 \\
RF & & \\
(D) Cross question consistency & 21.6 & 20.5 \\
Interest and inflation & 4.6 & 3.5 \\
All correct & 32.1 & 45.8 \\
None correct & 68.3 & 79.4 \\
At least 1 DK & 18.5 & 38.1 \\
All DK & 437 & 587 \\
Number of observations & Notes: Distribution of responses to financial literacy questions for respondents with \\
savings and without savings. DK indicates respondent answered “do not know”; $R F$ \\
indicates respondent chose "no answer.” All figures are weighted. \\
\end{tabular}

While cash serves as an important saving instrument in Central and Eastern Europe (Stix 2012), some respondents may not strictly distinguish between cash and current accounts used for daily transactional purposes and those used for savings. If we exclude respondents who hold only cash or a current account from the group of respondents with savings, we find higher levels of financial literacy 
among this group of savers: interest rate literacy is 53\% (compared to $47 \%$, Table 4) and inflation literacy is $43 \%$ (compared to $34 \%$, Table 4). Risk diversification literacy is lower at $14 \%$ compared to $18 \%$ (Table 4). The difference in inflation literacy is interesting to note, given that the main difference between the two groups are respondents who save in cash.

\section{Multivariate Model of Saving and Financial Literacy}

We now analyze whether the correlation shown in Table 4 between financial literacy and saving behavior persists in multivariate regression analysis. We control for age, gender, education, marital status, income, and labor market status. In addition, we control for household size and for whether the respondent is the head of household. Table 5 presents results from ordinary least squares (OLS) estimates. We employ two alternative dependent variables: the number of saving instruments (which is a measure of saving behavior and sophistication in saving behavior) and whether respondents have pension funds (which could be interpreted as a measure of retirement planning). In columns 1-3 the dependent variable ranges from zero to nine and counts the number of saving instruments the respondents possesses. In columns 4-6 the dependent variable is a dummy variable ${ }^{17}$ that takes the value one if the respondent saves in a pension fund. The percentage of respondents who save in a pension fund is very low, however, at 2\%. Therefore, results in columns 4-6 should be treated with some caution and only interpreted as providing an indication of saving behavior specific to retirement savings. ${ }^{18}$

Regarding sociodemographic characteristics, results are mixed. Age is not significant. More educated respondents are more likely to save, but results are also not significant. Households with children are more likely to save, whereas single respondents are less likely to save. Income is significantly and positively correlated with savings. Respondents who are not working are less likely to save in contrast to self-employed respondents, who are more likely to save. These results hold for the number of saving instruments but are less clear cut for pension funds.

To study the link between financial literacy and savings / pension funds, we include several alternative measures of financial literacy. Columns 1 and 4 include a dummy variable which is one if the respondent answers the interest, inflation, and risk diversification questions correctly. Columns 2 and 5 include a variable which ranges from 0 to 3 for the number of correct responses to the three literacy

\footnotetext{
${ }^{17}$ In empirical economics, binary (or indicator or categorical) variables are typically referred to as dummy variables. These variables takes the value of zero or one to indicate the absence or presence of some categorical effect.

${ }^{18}$ The dummy variable for pension funds is coded one any time the respondent names pension funds. It could be, therefore, that a respondent names eight saving instruments and mentions pension funds last. However, the majority of respondents have two interest-bearing saving instruments at most.
} 
questions. Finally, columns 3 and 6 include three dummy variables for answering each question correctly.

Table 5

OLS Estimates of Savings and Financial Literacy

\begin{tabular}{|c|c|c|c|c|c|c|}
\hline \multirow[b]{2}{*}{ Dependent Variable } & \multicolumn{3}{|c|}{ Number of saving instruments (0/9) } & \multicolumn{3}{|c|}{ Pension funds (0/1) } \\
\hline & $(1)$ & $(2)$ & (3) & (4) & (5) & (6) \\
\hline All three correct & $\begin{array}{c}-0.040 \\
(0.126)\end{array}$ & & & $\begin{array}{c}-0.003 \\
(0.026)\end{array}$ & & \\
\hline Total number correct & & $\begin{array}{l}0.084 * * * \\
(0.031)\end{array}$ & & & $\begin{array}{l}0.013^{* *} \\
(0.005)\end{array}$ & \\
\hline Inflation correct & & & $\begin{array}{l}0.086 \\
(0.065)\end{array}$ & & & $\begin{array}{l}0.026 * * \\
(0.010)\end{array}$ \\
\hline Interest correct & & & $\begin{array}{l}0.106 * \\
(0.058)\end{array}$ & & & $\begin{array}{l}0.011 \\
(0.010)\end{array}$ \\
\hline Risk correct & & & $\begin{array}{l}0.038 \\
(0.072)\end{array}$ & & & $\begin{array}{c}-0.007 \\
(0.012)\end{array}$ \\
\hline Age & $\begin{array}{c}-0.001 \\
(0.003)\end{array}$ & $\begin{array}{c}-0.001 \\
(0.003)\end{array}$ & $\begin{array}{c}-0.001 \\
(0.003)\end{array}$ & $\begin{array}{l}0.000 \\
(0.001)\end{array}$ & $\begin{array}{l}0.000 \\
(0.001)\end{array}$ & $\begin{array}{l}0.000 \\
(0.001)\end{array}$ \\
\hline Female & $\begin{array}{l}0.033 \\
(0.062)\end{array}$ & $\begin{array}{l}0.048 \\
(0.062)\end{array}$ & $\begin{array}{l}0.048 \\
(0.063)\end{array}$ & $\begin{array}{l}0.012 \\
(0.013)\end{array}$ & $\begin{array}{l}0.014 \\
(0.012)\end{array}$ & $\begin{array}{l}0.015 \\
(0.012)\end{array}$ \\
\hline High school graduate & $\begin{array}{l}0.068 \\
(0.066)\end{array}$ & $\begin{array}{l}0.045 \\
(0.066)\end{array}$ & $\begin{array}{l}0.045 \\
(0.066)\end{array}$ & $\begin{array}{l}0.013 \\
(0.011)\end{array}$ & $\begin{array}{l}0.010 \\
(0.011)\end{array}$ & $\begin{array}{l}0.010 \\
(0.011)\end{array}$ \\
\hline Some college & $\begin{array}{l}0.222 * * \\
(0.113)\end{array}$ & $\begin{array}{l}0.205^{*} \\
(0.113)\end{array}$ & $\begin{array}{l}0.203 * \\
(0.113)\end{array}$ & $\begin{array}{l}0.029 \\
(0.024)\end{array}$ & $\begin{array}{l}0.026 \\
(0.024)\end{array}$ & $\begin{array}{l}0.026 \\
(0.023)\end{array}$ \\
\hline College graduate & $\begin{array}{l}0.144 \\
(0.102)\end{array}$ & $\begin{array}{l}0.127 \\
(0.101)\end{array}$ & $\begin{array}{l}0.128 \\
(0.101)\end{array}$ & $\begin{array}{l}0.008 \\
(0.018)\end{array}$ & $\begin{array}{l}0.005 \\
(0.018)\end{array}$ & $\begin{array}{l}0.006 \\
(0.018)\end{array}$ \\
\hline Post Graduate & $\begin{array}{l}0.412 \\
(0.396)\end{array}$ & $\begin{array}{l}0.363 \\
(0.393)\end{array}$ & $\begin{array}{l}0.355 \\
(0.392)\end{array}$ & $\begin{array}{l}0.056 \\
(0.064)\end{array}$ & $\begin{array}{l}0.048 \\
(0.063)\end{array}$ & $\begin{array}{l}0.045 \\
(0.063)\end{array}$ \\
\hline Single & $\begin{array}{r}-0.158 * \\
(0.088)\end{array}$ & $\begin{array}{r}-0.151^{*} \\
(0.088)\end{array}$ & $\begin{array}{r}-0.150^{*} \\
(0.088)\end{array}$ & $\begin{array}{l}0.002 \\
(0.020)\end{array}$ & $\begin{array}{l}0.003 \\
(0.020)\end{array}$ & $\begin{array}{l}0.004 \\
(0.020)\end{array}$ \\
\hline Divorced & $\begin{array}{l}0.098 \\
(0.146)\end{array}$ & $\begin{array}{l}0.095 \\
(0.145)\end{array}$ & $\begin{array}{l}0.091 \\
(0.146)\end{array}$ & $\begin{array}{l}0.018 \\
(0.025)\end{array}$ & $\begin{array}{l}0.018 \\
(0.025)\end{array}$ & $\begin{array}{l}0.016 \\
(0.025)\end{array}$ \\
\hline Widowed & $\begin{array}{c}-0.142 \\
(0.091)\end{array}$ & $\begin{array}{l}-0.129 \\
(0.091)\end{array}$ & $\begin{array}{c}-0.133 \\
(0.091)\end{array}$ & $\begin{array}{l}0.001 \\
(0.026)\end{array}$ & $\begin{array}{l}0.003 \\
(0.026)\end{array}$ & $\begin{array}{l}0.003 \\
(0.026)\end{array}$ \\
\hline Income high & $\begin{array}{c}0.307^{* * *} \\
(0.096)\end{array}$ & $\begin{array}{l}0.287 * * * \\
(0.096)\end{array}$ & $\begin{array}{l}0.285^{* * *} \\
(0.096)\end{array}$ & $\begin{array}{l}0.011 \\
(0.018)\end{array}$ & $\begin{array}{l}0.008 \\
(0.018)\end{array}$ & $\begin{array}{l}0.008 \\
(0.018)\end{array}$ \\
\hline Income medium & $\begin{array}{l}0.050 \\
(0.075)\end{array}$ & $\begin{array}{l}0.034 \\
(0.076)\end{array}$ & $\begin{array}{l}0.032 \\
(0.076)\end{array}$ & $\begin{array}{c}-0.011 \\
(0.014)\end{array}$ & $\begin{array}{l}-0.013 \\
(0.014)\end{array}$ & $\begin{array}{l}-0.014 \\
(0.014)\end{array}$ \\
\hline Income no answer & $\begin{array}{l}0.019 \\
(0.072)\end{array}$ & $\begin{array}{l}0.022 \\
(0.072)\end{array}$ & $\begin{array}{l}0.019 \\
(0.073)\end{array}$ & $\begin{array}{c}-0.007 \\
(0.014)\end{array}$ & $\begin{array}{c}-0.006 \\
(0.014)\end{array}$ & $\begin{array}{c}-0.007 \\
(0.014)\end{array}$ \\
\hline Self-employed & $\begin{array}{l}0.716^{* *} \\
(0.304)\end{array}$ & $\begin{array}{l}0.710^{* * *} \\
(0.302)\end{array}$ & $\begin{array}{l}0.712^{* * *} \\
(0.302)\end{array}$ & $\begin{array}{l}0.134^{*} \\
(0.077)\end{array}$ & $\begin{array}{l}0.133^{*} \\
(0.076)\end{array}$ & $\begin{array}{l}0.134^{*} \\
(0.076)\end{array}$ \\
\hline Not working & $\begin{array}{c}-0.250 * * * \\
(0.065)\end{array}$ & $\begin{array}{c}-0.243^{* * *} \\
(0.065)\end{array}$ & $\begin{array}{c}-0.245 * * * \\
(0.065)\end{array}$ & $\begin{array}{l}-0.015 \\
(0.011)\end{array}$ & $\begin{array}{l}-0.014 \\
(0.010)\end{array}$ & $\begin{array}{l}-0.015 \\
(0.011)\end{array}$ \\
\hline 2 person household & $\begin{array}{l}0.020 \\
(0.102)\end{array}$ & $\begin{array}{l}0.023 \\
(0.101)\end{array}$ & $\begin{array}{l}0.020 \\
(0.101)\end{array}$ & $\begin{array}{l}0.012 \\
(0.023)\end{array}$ & $\begin{array}{l}0.013 \\
(0.023)\end{array}$ & $\begin{array}{l}0.013 \\
(0.023)\end{array}$ \\
\hline $3+$ person household & $\begin{array}{c}-0.126 \\
(0.104)\end{array}$ & $\begin{array}{c}-0.122 \\
(0.104)\end{array}$ & $\begin{array}{c}-0.124 \\
(0.104)\end{array}$ & $\begin{array}{c}-0.012 \\
(0.022)\end{array}$ & $\begin{array}{c}-0.011 \\
(0.022)\end{array}$ & $\begin{array}{c}-0.012 \\
(0.022)\end{array}$ \\
\hline Head of household & $\begin{array}{l}0.026 \\
(0.075)\end{array}$ & $\begin{array}{l}0.036 \\
(0.075)\end{array}$ & $\begin{array}{l}0.040 \\
(0.076)\end{array}$ & $\begin{array}{l}-0.010 \\
(0.015)\end{array}$ & $\begin{array}{l}-0.009 \\
(0.015)\end{array}$ & $\begin{array}{l}-0.007 \\
(0.014)\end{array}$ \\
\hline Children in household & $\begin{array}{l}0.207 * * \\
(0.081)\end{array}$ & $\begin{array}{l}0.210 * * \\
(0.081)\end{array}$ & $\begin{array}{l}0.210^{* * * *} \\
(0.081)\end{array}$ & $\begin{array}{l}0.014 \\
(0.016)\end{array}$ & $\begin{array}{l}0.014 \\
(0.016)\end{array}$ & $\begin{array}{l}0.014 \\
(0.016)\end{array}$ \\
\hline Constant & $\begin{array}{c}0.626 * * * \\
(0.190)\end{array}$ & $\begin{array}{l}0.527 * * * \\
(0.191)\end{array}$ & $\begin{array}{l}0.524^{* * * *} \\
(0.192)\end{array}$ & $\begin{array}{l}0.002 \\
(0.042)\end{array}$ & $\begin{array}{l}-0.013 \\
(0.041)\end{array}$ & $\begin{array}{c}-0.012 \\
(0.041)\end{array}$ \\
\hline$R^{2}$ & 0.13 & 0.13 & 0.13 & 0.05 & 0.05 & 0.06 \\
\hline$N$ & 1,029 & 1,029 & 1,029 & 1,029 & 1,029 & 1,029 \\
\hline
\end{tabular}


Results indicate that financial literacy does matter for saving behavior, but results are somewhat mixed. The dummy variable for "all three correct" in column 1 is insignificant. This is probably due to the very low percentage of respondents who are able to answer all three questions correctly and is similar to results of Almenberg and Säve-Söderbergh (2011). Similarly, we find no significant relationship between risk diversification literacy and savings, which may also be due to the low percentage of correct answers. ${ }^{19}$ By contrast, the "total number correct” is positively and significantly related to savings. For example, column 5 shows that correctly answering an additional financial literacy question raises the probability of saving in a pension fund by 1 percentage point (8 percentage points for the number of saving instruments). Columns 3 and 6 indicate that the effect of the categorical financial literacy measure reported in columns 2 and 4 is driven by being able to correctly answer the inflation or interest question.

Several specific factors can be relevant for savings and financial literacy levels in Romania. In Table 6, columns 1-3, we repeat the estimation shown in Table 5, columns 1-3, and extend the model to control for these factors. First, we include a dummy variable to control for memories of previous economic crises during transition, specifically hyperinflation. Results show that memories of hyperinflation are positively and significantly related to savings. In addition we proxy for the supply of banking services by including "bank perceived far." This variable is based on the question posed to all respondents, not just those with a banking relationship, to assess whether they perceive the nearest bank as being far away. It is negatively correlated with savings but insignificant.

Turning to the financial literacy measures in this specification we find a positive and significant correlation only between interest rate literacy and savings. However, the number of observations is rather low in these specifications due to the high nonresponse rate, in particular to the memory question. ${ }^{20}$

To account for the finding that in addition to transition experience, financial literacy varies with geography in Romania, Table 6 includes regional fixed effects. The regional effects are highly significant (results not shown). Our basic results, shown in Table 5, regarding the effect of financial literacy on savings do not change when we include regional fixed effects and cluster standard errors at the regional level.

\footnotetext{
${ }^{19}$ As we pointed out above, we do not have information on amounts saved. It could be the case that the amounts are very low and the cost of spreading them across saving instruments is comparatively too high. Not diversifying the portfolio would then reflect a sound financial decision.

${ }^{20}$ If we pool the data from fall 2011 and fall 2012, using a different measure of risk literacy for 2012, we find that higher levels of financial literacy are positively and significantly correlated with savings even after controlling for memories of hyperinflation and perceived distance to the nearest bank. In particular we find that inflation literacy is significant, which indicates that inflation literacy plays a role above and beyond the importance of previous economic experience.
} 
Table 6

Robustness Analysis

\begin{tabular}{|c|c|c|c|c|c|c|}
\hline \multirow[b]{2}{*}{ Dependent Variable } & \multicolumn{3}{|c|}{ Number of saving instruments $(0 / 9)$} & \multicolumn{3}{|c|}{$\begin{array}{c}\text { Number of saving instruments excluding } \\
\text { cash and current account }(0 / 7)\end{array}$} \\
\hline & (1) & $(2)$ & (3) & (4) & (5) & (6) \\
\hline All three correct & $\begin{array}{l}-0.166 \\
(0.189)\end{array}$ & & & $\begin{array}{r}-0.124^{*} \\
(0.071)\end{array}$ & & \\
\hline Number correct & & $\begin{array}{l}0.049 \\
(0.044)\end{array}$ & & & $\begin{array}{l}0.040 * * \\
(0.017)\end{array}$ & \\
\hline Inflation correct & & & $\begin{array}{l}0.059 \\
(0.089)\end{array}$ & & & $\begin{array}{l}0.097 * * \\
(0.040)\end{array}$ \\
\hline Interest correct & & & $\begin{array}{l}0.185^{* * *} \\
(0.080)\end{array}$ & & & $\begin{array}{l}0.042 \\
(0.032)\end{array}$ \\
\hline Risk correct & & & $\begin{array}{r}-0.179 * \\
(0.096)\end{array}$ & & & $\begin{array}{l}-0.066 \\
(0.042)\end{array}$ \\
\hline Remembers hyperinfl & $\begin{array}{l}0.196 * * \\
(0.082)\end{array}$ & $\begin{array}{l}0.190 * * \\
(0.082)\end{array}$ & $\begin{array}{l}0.171^{* * *} \\
(0.081)\end{array}$ & & & \\
\hline Bank perceived far & $\begin{array}{l}-0.021 \\
(0.026)\end{array}$ & $\begin{array}{l}-0.017 \\
(0.026)\end{array}$ & $\begin{array}{l}-0.020 \\
(0.026)\end{array}$ & & & \\
\hline Age & $\begin{array}{l}-0.004 \\
(0.003)\end{array}$ & $\begin{array}{l}-0.004 \\
(0.003)\end{array}$ & $\begin{array}{l}-0.004 \\
(0.003)\end{array}$ & $\begin{array}{l}-0.000 \\
(0.001)\end{array}$ & $\begin{array}{l}-0.000 \\
(0.001)\end{array}$ & $\begin{array}{l}-0.000 \\
(0.001)\end{array}$ \\
\hline Female & $\begin{array}{l}0.065 \\
(0.092)\end{array}$ & $\begin{array}{l}0.076 \\
(0.093)\end{array}$ & $\begin{array}{l}0.073 \\
(0.093)\end{array}$ & $\begin{array}{l}0.053 \\
(0.041)\end{array}$ & $\begin{array}{l}0.063 \\
(0.041)\end{array}$ & $\begin{array}{l}0.067 \\
(0.042)\end{array}$ \\
\hline High school graduate & $\begin{array}{l}0.019 \\
(0.094)\end{array}$ & $\begin{array}{c}-0.000 \\
(0.094)\end{array}$ & $\begin{array}{l}0.014 \\
(0.094)\end{array}$ & $\begin{array}{l}0.037 \\
(0.038)\end{array}$ & $\begin{array}{l}0.024 \\
(0.038)\end{array}$ & $\begin{array}{l}0.027 \\
(0.038)\end{array}$ \\
\hline Some college & $\begin{array}{l}0.071 \\
(0.158)\end{array}$ & $\begin{array}{l}0.060 \\
(0.159)\end{array}$ & $\begin{array}{l}0.041 \\
(0.163)\end{array}$ & $\begin{array}{l}0.114 \\
(0.075)\end{array}$ & $\begin{array}{l}0.104 \\
(0.075)\end{array}$ & $\begin{array}{l}0.101 \\
(0.075)\end{array}$ \\
\hline College graduate & $\begin{array}{l}0.054 \\
(0.132)\end{array}$ & $\begin{array}{l}0.054 \\
(0.132)\end{array}$ & $\begin{array}{l}0.057 \\
(0.130)\end{array}$ & $\begin{array}{l}0.112^{*} \\
(0.058)\end{array}$ & $\begin{array}{l}0.102 * \\
(0.058)\end{array}$ & $\begin{array}{l}0.105^{*} \\
(0.058)\end{array}$ \\
\hline Post Graduate & $\begin{array}{l}0.404 \\
(0.547)\end{array}$ & $\begin{array}{l}0.390 \\
(0.546)\end{array}$ & $\begin{array}{l}0.354 \\
(0.544)\end{array}$ & $\begin{array}{l}0.276 \\
(0.288)\end{array}$ & $\begin{array}{l}0.250 \\
(0.286)\end{array}$ & $\begin{array}{l}0.233 \\
(0.284)\end{array}$ \\
\hline Single & $\begin{array}{c}-0.168 \\
(0.123)\end{array}$ & $\begin{array}{c}-0.167 \\
(0.123)\end{array}$ & $\begin{array}{c}-0.165 \\
(0.122)\end{array}$ & $\begin{array}{c}-0.132 * * \\
(0.052)\end{array}$ & $\begin{array}{c}-0.127 * * \\
(0.052)\end{array}$ & $\begin{array}{c}-0.124 * * \\
(0.051)\end{array}$ \\
\hline Divorced & $\begin{array}{c}-0.056 \\
(0.196)\end{array}$ & $\begin{array}{c}-0.058 \\
(0.196)\end{array}$ & $\begin{array}{c}-0.093 \\
(0.199)\end{array}$ & $\begin{array}{l}0.081 \\
(0.109)\end{array}$ & $\begin{array}{l}0.080 \\
(0.108)\end{array}$ & $\begin{array}{l}0.071 \\
(0.108)\end{array}$ \\
\hline Widowed & $\begin{array}{r}-0.240^{*} \\
(0.128)\end{array}$ & $\begin{array}{r}-0.227^{*} \\
(0.126)\end{array}$ & $\begin{array}{r}-0.246^{*} \\
(0.127)\end{array}$ & $\begin{array}{r}-0.107^{*} \\
(0.060)\end{array}$ & $\begin{array}{c}-0.101^{*} \\
(0.059)\end{array}$ & $\begin{array}{r}-0.103^{*} \\
(0.060)\end{array}$ \\
\hline Income high & $\begin{array}{l}0.315^{* *} \\
(0.133)\end{array}$ & $\begin{array}{l}0.310 * * \\
(0.134)\end{array}$ & $\begin{array}{l}0.300^{* * *} \\
(0.132)\end{array}$ & $\begin{array}{l}0.169 * * * \\
(0.058)\end{array}$ & $\begin{array}{l}0.156^{* * *} \\
(0.057)\end{array}$ & $\begin{array}{l}0.156^{* * *} \\
(0.057)\end{array}$ \\
\hline Income medium & $\begin{array}{l}-0.030 \\
(0.119)\end{array}$ & $\begin{array}{c}-0.034 \\
(0.119)\end{array}$ & $\begin{array}{c}-0.052 \\
(0.118)\end{array}$ & $\begin{array}{l}0.087^{* *} \\
(0.043)\end{array}$ & $\begin{array}{l}0.075^{*} \\
(0.044)\end{array}$ & $\begin{array}{l}0.074^{*} \\
(0.044)\end{array}$ \\
\hline Income no answer & $\begin{array}{l}0.142 \\
(0.130)\end{array}$ & $\begin{array}{l}0.147 \\
(0.131)\end{array}$ & $\begin{array}{l}0.151 \\
(0.129)\end{array}$ & $\begin{array}{l}0.051 \\
(0.043)\end{array}$ & $\begin{array}{l}0.051 \\
(0.043)\end{array}$ & $\begin{array}{l}0.048 \\
(0.043)\end{array}$ \\
\hline Self-employed & $\begin{array}{l}0.734^{* *} \\
(0.360)\end{array}$ & $\begin{array}{l}0.718 * * \\
(0.359)\end{array}$ & $\begin{array}{l}0.721 * * \\
(0.355)\end{array}$ & $\begin{array}{l}0.364 * \\
(0.217)\end{array}$ & $\begin{array}{l}0.360^{*} \\
(0.217)\end{array}$ & $\begin{array}{l}0.364 * \\
(0.215)\end{array}$ \\
\hline Not working & $\begin{array}{c}-0.325 * * * \\
(0.096)\end{array}$ & $\begin{array}{c}-0.319 * * * \\
(0.095)\end{array}$ & $\begin{array}{l}-0.330^{* * *} \\
(0.096)\end{array}$ & $\begin{array}{c}-0.057 \\
(0.039)\end{array}$ & $\begin{array}{c}-0.053 \\
(0.038)\end{array}$ & $\begin{array}{l}-0.056 \\
(0.038)\end{array}$ \\
\hline 2 person household & $\begin{array}{l}0.018 \\
(0.151)\end{array}$ & $\begin{array}{l}0.023 \\
(0.151)\end{array}$ & $\begin{array}{c}-0.008 \\
(0.152)\end{array}$ & $\begin{array}{c}-0.065 \\
(0.068)\end{array}$ & $\begin{array}{c}-0.061 \\
(0.068)\end{array}$ & $\begin{array}{l}-0.065 \\
(0.068)\end{array}$ \\
\hline $3+$ person household & $\begin{array}{r}-0.287^{*} \\
(0.153)\end{array}$ & $\begin{array}{r}-0.279 * \\
(0.152)\end{array}$ & $\begin{array}{c}-0.306^{* *} \\
(0.153)\end{array}$ & $\begin{array}{c}-0.142^{* *} \\
(0.061)\end{array}$ & $\begin{array}{c}-0.138 * * \\
(0.061)\end{array}$ & $\begin{array}{c}-0.140 * * \\
(0.061)\end{array}$ \\
\hline Head of household & $\begin{array}{l}0.056 \\
(0.112)\end{array}$ & $\begin{array}{l}0.058 \\
(0.112)\end{array}$ & $\begin{array}{l}0.081 \\
(0.113)\end{array}$ & $\begin{array}{c}-0.035 \\
(0.047)\end{array}$ & $\begin{array}{l}-0.029 \\
(0.047)\end{array}$ & $\begin{array}{l}-0.020 \\
(0.048)\end{array}$ \\
\hline Children in household & $\begin{array}{l}0.221^{*} \\
(0.117)\end{array}$ & $\begin{array}{l}0.208 * \\
(0.118)\end{array}$ & $\begin{array}{l}0.224^{*} \\
(0.116)\end{array}$ & $\begin{array}{l}0.068 \\
(0.045)\end{array}$ & $\begin{array}{l}0.069 \\
(0.045)\end{array}$ & $\begin{array}{l}0.068 \\
(0.045)\end{array}$ \\
\hline Constant & $\begin{array}{l}1.344^{* * * *} \\
(0.326)\end{array}$ & $\begin{array}{c}1.254^{* * *} \\
(0.330)\end{array}$ & $1.292 * * *$ & $0.283^{* *}$ & $0.222^{*}$ & $0.219^{*}$ \\
\hline Regional fixed effects & Yes & Yes & Yes & Yes & Yes & Yes \\
\hline$R^{2}$ & 0.19 & 0.19 & 0.20 & 0.10 & 0.11 & 0.11 \\
\hline$N$ & 588 & 588 & 588 & 1029 & 1029 & 1029 \\
\hline
\end{tabular}


To address the concern that the dependent variable (number of saving instruments) might include respondents who only have cash or a current account for transaction purposes and not specifically for savings, we use an alternative dependent variable (Table 6, columns 4-6). This variable counts the number of saving instruments but does not define cash and current account as saving instruments. Regarding financial literacy, the negative coefficient for respondents who answer all three questions correctly is surprising. However, column 5 confirms the positive and significant correlation between savings and financial literacy. The main difference between Table 5 column 3 and Table 6 column 6 are cash savers. Interestingly, column 6 shows a positive and significant effect of inflation literacy for non-cash savers.

We further check the robustness of our results by including proxies for wealth (a dummy for homeownership) and controlling for economic expectations. Wealth is positively correlated with savings but might be endogenous. Therefore, we do not include it in the baseline specification. Our sample includes respondents who are 14-18 years old. To make sure that our results are not influenced by responses from young respondents who do not have to make financial decisions, we re-run regressions for the subsample of respondents who are 18 and older.

One concern with the estimations in Tables 5 and 6 is the fact that financial literacy may itself be endogenous. On the one hand, financial literacy could increase with experience and causality could, in fact, run from saving to financial literacy. One could argue that this effect is less important for Romania, as the experience with a market-based financial system is still fairly short. On the other hand, however, there might be unobserved factors that drive both the saving decision and financial literacy.

Lastly, a number of papers discuss the difficulties in measuring financial literacy (e.g., Atkinson and Messy 2012); our results on literacy levels may be subject to measurement error. We try to address this by using instrumental variables regressions. However, finding suitable instruments is extremely difficult. ${ }^{21}$ This is an area for future work.

\section{Conclusion}

New evidence using internationally comparable measures of financial literacy from the Euro Survey shows that financial literacy in Romania is among the lowest in Central, Eastern, and Southeastern Europe and also low compared to other countries studied in the Financial Literacy around the World project. Similar to findings in other countries, older respondents, women, and less-educated individuals perform worst on the financial literacy questions. However, we show

${ }^{21}$ Behrman et al. (2010) provide a detailed discussion of possible instruments. 
that those who remember economic turbulence during the transition period have a higher level of financial literacy, thus somewhat counteracting the age effect. In addition, findings suggest a strong regional disparity in financial literacy levels in Romania, which cannot be fully explained by sociodemographic differences among regions.

Financial literacy has a positive impact on saving behavior in Romania. Individuals who are financially literate, especially with regard to inflation, are more likely to save using more than one interest-bearing saving instrument. They are also more likely to invest in pension funds. These findings confirm results from previous research that financial literacy is positively related to financial behavior.

Advancing this positive effect of financial literacy on financial behavior by investing in financial education may be beneficial for policy makers in Romania. It may help to promote demand for financial services related to savings and limit mistakes in financial decisions related to borrowing.

\section{Acknowledgments}

I wish to especially thank Annamaria Lusardi for her invaluable guidance and very useful suggestions. I am also very grateful to the three anonymous referees and Audrey Brown for their helpful comments and detailed feedback. Helmut Stix has generously shared his expertise of the Euro Survey data with me and was supportive and happy to discuss any questions I had. Peter Backé and Mabel Beckmann provided timely assistance on the final draft. The views are those of the author and do not necessarily reflect those of the Eurosystem or the Oesterreichische Nationalbank.

\section{References}

Abreu, M., and V. Mendes. 2010. Financial literacy and portfolio diversification. Quantitative Finance 10(5): 515-528. http://dx.doi.org/10.1080/14697680902878105

Alessie, R., M. van Rooij, and A. Lusardi. 2011. Financial literacy and retirement preparation in the Netherlands. Journal of Pension Economics and Finance 10(4): 527-545. http://dx.doi.org/10.1017/S1474747211000461

Almenberg, J., and J. Säve-Södenbergh. 2011. Financial literacy and retirement planning in Sweden. Journal of Pension Economics and Finance 10(4): 585598. http://dx.doi.org/10.1017/S1474747211000497

Atkinson, A., and F. Messy. 2012. Measuring financial literacy: Results of the OECD / International Network on Financial Education (INFE) pilot study. OECD Working Papers on Finance, Insurance and Private Pensions No. 15. OECD Publishing. http://dx.doi.org/10.1787/5k9csfs90fr4-en 
Beckmann, E., and H. Stix. 2013. Foreign currency loans and knowledge of exchange rate risk. OeNB Working Paper forthcoming. Oesterreichische Nationalbank, Vienna, Austria.

Beckmann, E., and T. Scheiber. 2012. The impact of memories of high inflation on households' trust in currencies. Focus on European Economic Integration $\mathrm{Q} 4 / 12$. http://www.oenb.at/de/presse pub/period pub/volkswirtschaft/integration/foc us_on_european_economic_integration_12q4.jsp\#tcm:14-251604

Behrman, J. R., O. S. Mitchell, C. Soo, and D. Bravo. 2010. Financial literacy, schooling, and wealth accumulation. NBER Working Paper No. 16452. National Bureau of Economic Research, Cambridge, MA. http://www.nber.org/papers/w16452.pdf

Bucher-Koenen, T., and A. Lusardi. 2011. Financial literacy and retirement planning in Germany. Journal of Pension Economics and Finance 10(4): 565584. http://dx.doi.org/10.1017/S1474747211000485

Bumcrot, C. B., J. Lin, and A. Lusardi. 2013. The geography of financial literacy. Numeracy 6(2). http://dx.doi.org/10.5038/1936-4660.6.2.2

Cardak, B. A., and R. Wilkins. 2009. The determinants of household risky asset holdings: Australian evidence on background risk and other factors. Journal of Banking and Finance 33(5): 850-860. http://dx.doi.org/10.1016/j.jbankfin.2008.09.021

Christelis, D., Jappelli, T., and Padula, M. Cognitive abilities and portfolio choice. European Economic Review 54(1): 18-38. http://dx.doi.org/10.1016/j.euroecorev.2009.04.001

Cole, S., T. Sampson, B. Zia. 2011. Prices or knowledge? What drives demand for financial services in emerging markets? Journal of Finance 66(6): 1933-1967. http://dx.doi.org/10.1111/j.1540-6261.2011.01696.x

EBRD. See European Bank for Reconstruction and Development.

European Bank for Reconstruction and Development. 2011. Transition Report. London, United Kingdom: Fulmar.

Fidrmuc, J., M. Hake, and H. Stix. 2013. Households' foreign currency borrowing in Central and Eastern Europe. Journal of Banking and Finance 37(6): 18801897. http://dx.doi.org/10.1016/j.jbankfin.2012.06.018

Fornero, E., and C. Monticone. 2011. Financial literacy and pension plan participation in Italy. Journal of Pension Economics and Finance 10(4): 547564. http://dx.doi.org/10.1017/S1474747211000473

Gathergood, J. 2012. Self-control, financial literacy and consumer over-indebtedness. Journal of Economic Psychology 33(3): 590-602. http://dx.doi.org/10.1016/j.joep.2011.11.006 
Jappelli, T., and M. Padula. 2013. Consumption growth, the interest rate, and financial literacy. CEPR Discussion Paper No. 9406. Centre for Economic Policy Research, London, UK. http://www.cepr.org/pubs/dps/DP9406.asp Klapper, L., and G. A. Panos. 2011. Financial literacy and retirement planning: The Russian case. Journal of Pension Economics and Finance 10(4): 599-618. http://dx.doi.org/10.1017/S1474747211000503

Laeven, L., and F. Valencia. 2008. Systemic banking crises: A new database. IMF Working Paper No. 224. International Monetary Fund Publications. http://www.imf.org/external/pubs/cat/longres.cfm?sk=22345.0

Lusardi, A., and O. S. Mitchell. 2011a. Financial literacy and planning: Implications for retirement wellbeing. In Financial Literacy: Implications for Retirement Security and the Financial Marketplace. Oxford Scholarship Online. http://dx.doi.org/10.1093/acprof:oso/9780199696819.001.0001

- 2011b. Financial literacy and retirement planning in the United States. Journal of Pension Economics and Finance 10(4): 509-525. http://dx.doi.org/10.1017/S147474721100045X

- 2011c. Financial literacy around the world: An overview. Journal of Pension Economics and Finance 10(4): 497-508. http://dx.doi.org/10.1017/S1474747211000448

Lusardi, A., and P. Tufano. 2009. Debt literacy, financial experiences, and overindebtedness. NBER Working Paper No. 14808. National Bureau of Economic Research, Cambridge, MA. http://www.nber.org/papers/w14808.pdf

Scheiber, T., and H. Stix. 2009. Euroization in Central, Eastern and Southeastern Europe-New evidence on its extent and some evidence on its causes. OeNB Working Paper No. 159. Oesterreichische Nationalbank, Vienna, Austria. http://www.oenb.at/de/img/wp159_tcm14-144505.pdf

Sekita, S. 2011. Financial literacy and retirement planning in Japan. Journal of Pension Economics and Finance 10(4): 637-656. http://dx.doi.org/10.1017/S1474747211000527

Stix, H. 2011. Euroization: What factors drive its persistence? Household data evidence for Croatia, Slovenia and Slovakia. Applied Economics 43(21): 2689-2704. http://dx.doi.org/10.1080/00036840903357413

- 2012. Why do people save in cash? Distrust, memories of banking crises, weak institutions and dollarization. OeNB Working Paper No. 178. Oesterreichische Nationalbank, Vienna, Austria. http://www.oenb.at/de/img/working_paper_178_tcm14-249425.pdf

van Rooij, M., A. Lusardi, and R. Alessie. 2011. Financial literacy and stock market participation. Journal of Financial Economics 101(2): 449-472. http://dx.doi.org/10.1016/j.jfineco.2011.03.006 


\section{Appendix}

Table A1

Interest Rate Literacy in Euro Survey Countries by Education Levels

\begin{tabular}{lcccccc}
\hline Education & Primary & $\begin{array}{c}\text { Lower } \\
\text { secondary }\end{array}$ & $\begin{array}{c}\text { (Upper) } \\
\text { secondary }\end{array}$ & $\begin{array}{c}\text { Postsecondary } \\
\text { non-tertiary }\end{array}$ & $\begin{array}{c}\text { First stage of } \\
\text { tertiary }\end{array}$ & $\begin{array}{c}\text { Second stage of } \\
\text { tertiary }\end{array}$ \\
\hline Albania & 0.50 & 0.65 & 0.57 & & 0.61 & 0.67 \\
Bosnia and & 0.48 & 0.65 & 0.67 & 0.61 & 0.72 & 0.57 \\
$\quad$ Herzegovina & & & & 0.67 & 0.56 & 0.56 \\
Bulgaria & 0.10 & 0.43 & 0.48 & 0.72 & 0.44 & 0.63 \\
Croatia & 0.61 & 0.60 & 0.71 & 0.78 & 0.83 & 0.82 \\
Czech Republic & 0.46 & 0.60 & 0.70 & 0.60 & 0.65 & 0.63 \\
FYR Macedonia & 0.64 & 0.84 & 0.71 & 0.62 & 0.74 & 0.88 \\
Hungary & 0.55 & 0.68 & 0.70 & 0.52 & 0.55 & 0.58 \\
Poland & 0.37 & 0.57 & 0.55 & 0.70 & 0.73 & 0.80 \\
Serbia & 0.37 & 0.55 & 0.58 & & & \\
\hline
\end{tabular}

Notes: Distribution of interest rate literacy responses by educational level in remaining countries covered by the Euro Survey.

Table A2

Descriptive Statistics

\begin{tabular}{|c|c|c|c|c|}
\hline & \multicolumn{2}{|c|}{ Other Euro Survey countries } & \multicolumn{2}{|c|}{ Romania } \\
\hline & Mean & $\mathrm{SD}$ & Mean & SD \\
\hline Age & 43 & 17.06 & 44 & 18.32 \\
\hline Female & 0.51 & 0.50 & 0.52 & 0.50 \\
\hline Education Low & 0.29 & 0.45 & 0.32 & 0.46 \\
\hline Education Medium & 0.57 & 0.50 & 0.50 & 0.50 \\
\hline Education High & 0.14 & 0.35 & 0.18 & 0.39 \\
\hline Single & not available & & 0.24 & 0.42 \\
\hline Divorced & not available & & 0.05 & 0.23 \\
\hline Widowed & not available & & 0.13 & 0.33 \\
\hline Income high & 0.23 & 0.42 & 0.22 & 0.41 \\
\hline Income medium & 0.24 & 0.42 & 0.22 & 0.41 \\
\hline Income low & 0.36 & 0.48 & 0.23 & 0.42 \\
\hline Income no answer & 0.17 & 0.38 & 0.33 & 0.47 \\
\hline Self-employed & 0.06 & 0.24 & 0.02 & 0.14 \\
\hline Not working & 0.50 & 0.50 & 0.61 & 0.49 \\
\hline 2-person household & 0.25 & 0.43 & 0.30 & 0.46 \\
\hline $3+$ person household & 0.65 & 0.48 & 0.51 & 0.50 \\
\hline Head of household & 0.53 & 0.50 & 0.59 & 0.49 \\
\hline $\begin{array}{l}\text { Children in } \\
\text { household }\end{array}$ & 0.35 & 0.48 & 0.28 & 0.45 \\
\hline $\begin{array}{l}\text { Remembers } \\
\text { hyperinflation }\end{array}$ & 0.57 & 0.50 & 0.65 & 0.48 \\
\hline Bank perceived far & 0.38 & 0.48 & 0.57 & 0.50 \\
\hline
\end{tabular}

Notes: The table shows the sample means and standard deviations (SD) of respective variables. Figures for Other Euro Survey countries are the average of the nine remaining countries without adjusting for country size. Some variables are not available in exactly the same specification for the entire sample and Romania. Therefore, we show education on a more aggregate level (university level, medium level, and basic education). Income categories are dummy variables that take the value one for each net household income terciles (high, medium, low). Sample values are used to construct terciles. For those respondents who did not give an answer, an additional dummy variable is defined (income no answer). "Not working” includes retired, unemployed, students, and other nonworking respondents. In the estimation, "bank perceived far" is included as a categorical variable ranging from 1 to 6; in the descriptive statistics we show the percentage of respondents who perceive banks as far, i.e., including all who answer 4 to 6 . 